\title{
Candiduria in adults and children: prevalence and antifungal susceptibility in outpatient of Jataí-G0
}

\author{
Candidúria em adultos e crianças: prevalência e suscetibilidade a \\ antifúngicos em pacientes ambulatoriais de Jataí-GO
}

Izabela Alves de Sousa'; Alexandre Braoios'; Thaynara Gonzaga Santos ${ }^{3}$; Juliano Alves de Lima ${ }^{3}$; Rafael Menezes da Costa ${ }^{4}$

\begin{abstract}
Introduction: The term candiduria refers to the presence of yeast in urine and Candida albicans is the most common agent. In general, routine laboratories do not perform identification and cultivation of yeast. Objectives: To determine the prevalence of Candida species and to evaluate the antifungal susceptibility of the species isolated in urine of outpatients Jataí-G0, between January-October 2013. Material and method: Urine samples containing fungal structures were plated out on Sabouraud agar with chloramphenicol. Differentiation was taken with the urease test, nitrogen and carbon sources assimilation, germ tube test, morphology on cornmeal agar and chromogenic agar cultivation. Susceptibility was evaluated at antifungal itraconazole, fluconazole, amphotericin B and ketoconazole. Results: 1,215 urine tests were performed, and 64 had fungal structures (5.3\%). Two samples were lost, thus here we considered 62 isolates. From this total, 43 were identified as C. albicans (67.2\%), eight $C$. glabrata (12.5\%), five C. krusei (7.8\%), three $C$. tropicalis ( $4.7 \%$ ), and three could not determine the species (4.7\%). Amphotericin B and ketoconazole inhibited $94.9 \%$ of the isolates. On the other hand, $55.9 \%$ and $54.2 \%$ were resistant to itraconazole and fluconazole, respectively. The resistance rates of both fluconazole and itraconazole for $C$. glabrata and $C$. albicans, as fluconazole for $C$. albicans and $C$. krusei, showed significant differences $(\phi<0.05)$. Conclusion: These data demonstrate the importance of conducting a full identification and susceptibility to antifungal agents in samples with yeast infection.
\end{abstract}

Keywords: antifungal susceptibility test; amphotericin B; Candida; candiduria; fluconazole; ketoconazole; itraconazole.

\section{INTRODUCTION}

The term candiduria refers to the presence of yeast in urine, either by the microscope observation of pseudohyphae, budding and not budding yeast, or by the grow of fungi in culture ${ }^{(19)}$. Candiduria is very common in patient exposed to risk factors, mainly hospitalized patients, diabetic, and specially those admitted to the Intensive Care Utnit (ICU) ${ }^{(8)}$.

Among Candida species, C. albicans is the most common and most pathogenic agent, and, therefore, the most widely studied $^{(21)}$. This fungus is dimorphic and opportunistic, thus, with chronic disease or immunodeficiency situation, or even with normal microbiota imbalance, candidiasis may manifest. Surveillance studies show that most common risk factors for urinary tract infections (UTI) include: instrumentation of urinary tract, surgical procedures, antibiotic use, advanced age, female gender, diabetes mellitus, immunosuppressive therapy, and prolonged hospitalization ${ }^{(4,19)}$.

Despite the prevalence of Candida albicans, there has been an increase in the incidence of non-albicans yeast species as causative agents of infection, including UTI, and C. glabrata, C. tropicalis, C. parapsilosis, C. krusei, C. lusitaniae, and C. guilliermondi are more common. Epidemiologic studies in Brazil show that the three most prevalent species isolated from urine are C. albicans, C. tropicalis, and C. glabrata $^{(8,17)}$.

Although the quantification and identification of yeasts in urine are not routinely performed, it is essential to identify the etiologic agent, since the pathogenicity and the susceptibility pattern to antifungal present variations according to specie.

First submission on 13/04/14; last submission on 09/06/14; accepted for publication on 09/06/14; published on 20/08/14

1. Biomedical Scientist-Universidade Federal de Goiás (UFG), regional Jataí.

2. Phd in Clinical Analysis-Universidade Estadual Paulista (UNESP); associate professor at UFG-Jataí.

3. Biomedical student-UFG-Jataí; fellowship at Laboratory of Bacteriology and Mycology at UFG-Jataí.

4. Biomedical student-UFG-Jataí; master in Pharmacology at Universidade de São Paulo (USP), Ribeirão Preto. 
Studies report that $C$. glabrata e $C$. krusei specie are, in general, resistant to azole antifungals class, such as fluconazole, so it is necessary to use another antifungal to combat the infection caused by these species, such as amphotericin $\mathrm{B}^{(2)}$.

Generally, routine laboratory practice is limited to report the presence of fungal structure in urine, when observed in urine sediment. It is not common practice the complete identification and the antifungal susceptibility test; this fact may endanger the effectiveness of antimicrobial therapy and the patient's health, since different species may have different virulence and susceptibility to differentiated antifungal. Failure in microbial identification also endangers important epidemiologic data, such as regional prevalence of the species involved in infectious processes. Thus, this study may provide data on the prevalence of urinary tract infections caused by different species of Candida, as well as the evaluation of antifungal susceptibility profile to these microorganisms. Patients with predisposing factors, such as diabetes and use of antibiotics are more susceptible to fungal infections. These data may contribute to the laboratory practice, showing the importance of performing fungal identification, and also to local medical professionals, since it was been shown that susceptibility profile to antifungal may vary according to the specie involved in the infection ${ }^{(2)}$, specially when it comes to patients at risk of opportunistic infections. Thus, the present study has as its primary justification to reveal the incidence of major species of Candida sp. in the studied population, as well as its susceptibility profiles to the antifungal most commonly used in therapy, as a way of contributing to local medical professionals regarding epidemiology and resistance of these microorganisms.

\section{MATERIAL AND METHOD}

\section{Design and ethics in research}

Descriptive and correlational epidemiological study aiming to determine the frequency of Candida species isolated from urine, in the period Janeiro-October 2013, in the city of Jataí-GO. The project was submitted and approves by the Ethics Committee of Universidade Federal de Goiás (protocol 238/11).

\section{Patients and biological samples}

Participated in this study two private laboratories at city of Jataí-GO, which serve patients from the community. In the period Janeiro-October 2013, it was performed 1215 urine exams in patients of both sexes, with predominance of female patient (93.8\%), aged between 2 and 82 years, with predominance of patients between
20 and 60 years of age (62.5\%). The urine sample form patients routinely attended in laboratories, which presented fungal structures at microscopy, were cultivated by laboratory professionals in the Sabouraud Dextrose with Cloranfenicol agar culture medium. After microbial growth, the cultures were transported to the Laboratório de Bacteriologia e Micologia at Universidade Federal de Goiás (UFG), Campus Jataí. From 1215 total samples collected in the period, it was selected 64 samples for this study, corresponding to $5.3 \%$ of total sample in the period. Intending to only include the samples that could actually characterize Candida infection, the following criteria were adopted: (i) leukocytes presence; (ii) reporting of symptoms characteristic of urinary tract infection; and (iii) isolation of any other etiologic agent in the sample. The selected samples were stored in a freezer $\left(-20^{\circ} \mathrm{C}\right)$, until the time of analysis. However, two samples were lost during this process, so the total number of samples analyzed was 62 strains.

\section{Microbial identification}

The strain differentiation was performed with the urease and nitrogen assimilation tests. Candida yeasts are unable to hydrolyze urea and to assimilate potassium nitrate. Species identifications were performed by germ-tube test, micromorphology in cornmeal agar, assimilation of carbon sources (carbohydrates), and morphology in chromogenic agar ${ }^{(16,22)}$.

\section{Antifungal susceptibility test}

The agar diffusion test or antifungal susceptibility test was performed according to the document M44-A2 of Clinical and Laboratory Stardards Institute (CLSI). The antifungal fluconazole $(25 \mu \mathrm{g})$, ketoconazole $(50 \mu \mathrm{g})$, itraconazole $(10 \mu \mathrm{g})$, and amphotericin B $(100 \mu \mathrm{g})$ were evaluated. It was used the Mueller Hinton Agar culture medium supplemented with $2 \%$ of glucose and $0.5 \mu \mathrm{g} / \mathrm{ml}$ of methylene blue. The yeast suspension was adjusted to contain 1 to $5 \times 10^{6}$ cells $/ \mathrm{ml}$, which corresponds to 0.5 tube in McFarland turbidity scale. The antifungal discs were placed in sites previously marked on plate over the solid agar. The plates were incubated for 24 to $48 \mathrm{~h}$, at $35^{\circ} \mathrm{C}$. The reading was performed according to the antifungal discs manufacture's recommendations, measuring the growth inhibition halo. Results were expressed as susceptible, intermediate, and resistant ${ }^{(7)}$.

\section{Strains controle}

To control of identification test and antifungal susceptibility test, we used the C. albicans ATCC 90028, C. parapsilosis ATCC 22019, and C. krusei ATCC 6258 strains. 


\section{Statistical analysis}

Resistance rates of the most prevalent species were subjected to statistical analysis by Graphpad Prisma software, using Fisher exact test with confidence interval (CI) of 95\%.

\section{RESULTS}

From the 64 samples previously selected for the study, two were lost during storage (3.1\%). I addition, three samples (4.7\%) could not be completely identified with the methodology used, and therefore classified as Candida spp. Excluding the two lost samples, the prevalence of 62 species was distribute as follows: Candida albicans was the most prevalent specie, representing $69.3 \%$ of the samples, followed by C. glabrata (12.9\%), C. krusei (8.1\%), C. tropicalis (4.8\%), and Candida sp. (4.8\%).

From the total of 64 samples, the antifungal susceptibility test was performed for 59 of them, considering that two were lost and the antifungal susceptibility test was not performed for three C. albicans isolates. From this total, 56 (94.9\%) were susceptible to amphotericin $B$ and ketoconazole antifungal. The species were more resistant to fluconazole (54.2\%) and itraconazole (55.9\%) drugs. Data regarding antifungal susceptibility test are showed on Table. Statistical analysis showed significant differences in resistance rates of $C$. albicans and $C$. glabrata to itraconazole and fluconazole, and also between resistance rates of $C$. albicans and $C$. krusei species.

\section{DISCUSSION}

The aim of this study was to identify Candida species isolated from urine samples of outpatients. The identification of species that causes fungal infections is epidemiologically and clinically interesting, since the literature shows reports of different susceptibility profiles among species. Atique $(2006)^{(2)}$ reports that $C$. glabrata and C. krusei species are generally resistant to

TABLE - Susceptibility profile of Candida strain (62) isolated from outpatients urine samples of both sexes, aged between 2 and 82 years of age, in the period January-October 2013, in the city of Jataí-G0

\begin{tabular}{|c|c|c|c|c|}
\hline \multirow[t]{2}{*}{ Specie $(n)$} & \multirow[t]{2}{*}{ Antifungal } & \multicolumn{3}{|c|}{ Antifungal susceptibility test results $n(\%)$} \\
\hline & & $S$ & $\mathrm{R}$ & $\mathrm{NT}^{*}$ \\
\hline \multirow{3}{*}{ C. albicans (43) } & Itraconazole & $23(53.5 \%)$ & $17(39.5 \%)^{\mathrm{a}}$ & $3(7 \%)$ \\
\hline & Amphotericin B & $39(90.7 \%)$ & $1(2.3 \%)$ & $3(7 \%)$ \\
\hline & Ketoconazole & $39(90.7 \%)$ & $1(2.3 \%)$ & $3(7 \%)$ \\
\hline \multirow{3}{*}{ C. glabrata (8) } & Fluconazole & $1(12.5 \%)$ & $7(87.5 \%)^{\mathrm{b}}$ & $0(0 \%)$ \\
\hline & Amphotericin B & $7(87.5 \%)$ & $1(12.5 \%)$ & $0(0 \%)$ \\
\hline & Ketoconazole & $7(87.5 \%)$ & $1(12.5 \%)$ & $0(0 \%)$ \\
\hline \multirow{2}{*}{ C. krusei (5) } & Itraconazole & $1(20 \%)$ & $4(80 \%)$ & $0(0 \%)$ \\
\hline & Fluconazole & $0(0 \%)$ & $5(100 \%)^{c}$ & $0(0 \%)$ \\
\hline \multirow{3}{*}{ C. tropicalis (3) } & Fluconazole & $1(33.3 \%)$ & $2(66.7 \%)$ & $0(0 \%)$ \\
\hline & Amphotericin B & $3(100 \%)$ & $0(0 \%)$ & $0(0 \%)$ \\
\hline & Ketoconazole & $3(100 \%)$ & $0(0 \%)$ & $0(0 \%)$ \\
\hline \multirow{4}{*}{ Candida spp. (3) } & Itraconazole & $0(0 \%)$ & $0(0 \%)$ & $3(100 \%)$ \\
\hline & Fluconazole & $0(0 \%)$ & $0(0 \%)$ & $3(100 \%)$ \\
\hline & Amphotericin B & $0(0 \%)$ & $0(0 \%)$ & $3(100 \%)$ \\
\hline & Ketoconazole & $0(0 \%)$ & $0(0 \%)$ & $3(100 \%)$ \\
\hline
\end{tabular}

${ }^{*}$ NT: not tested; ${ }^{a}: \mathrm{p}=0.0479 ;{ }^{b}: \mathrm{p}=0.0479 ;{ }^{c}: \mathrm{p}=0.0216$. 
the antifungal fluconazole, which is the first choice drug, so it is necessary to use another antifungal against the infection caused by these species, such as amphotericin B. In this study, $87.5 \%$ of C. glabrata species were resistant to fluconazole, and $100 \%$ of the C. krusei isolates were resistant to this drug, illustrating this problem.

The standardization of urine culture requires quantification of the microorganisms; however, yeast quantification is not performed routinely by laboratories, unless there is specific medical request, since these agents do not have high prevalence. Overall, the examination report presents only the account of fungal structures observed in urinary sediment. Once most patients with candiduria are asymptomatic and shows no signs or symptoms associated, some authors considers quantifying an important criterion to obtain confirmation in case of infection, but a default value has not been defined. The count 1000-10000 UFC/ml suggests diagnosis of candiduria, whereas urinary tract infection is characterized by high colonization and higher count than $10000 \mathrm{UFC} / \mathrm{ml}^{(11,13)}$. However, yeast quantification requires the use of a suitable culture medium, and including microbiologic examination depends on the medical request. Clinical analysis laboratories for routine exams only report the presence of fungal structures in the urinary sediment.

The presence of Candida sp. in urine, both on direct examination and in culture, does not imply clinical or diagnostic significance, it may occur due to contamination. According to Canuto et al. $(2002)^{(5)}$, the determination of candiduria term may be controversial and difficult to understand, because the criteria are not fully defined to reliably differentiate a urinary tract infection caused by fungus or just a contamination. According to Malani et al. $(2007)^{(14)}$, in cases of infection by Candida species, the urinary sediment commonly presents erythrocytes, leukocytes, yeasts, and pseudohyphae. However, the absence of these changes does not eliminate the possibility of fungal infection, this frequently occurs when candiduria is secondary to systemic infection. In this study, Candida sp. was considered the possible etiologic agent of urinary tract infection, according to the following criteria: (i) absence of other microorganisms in the urine sample; (ii) increase in leukocyte number; and (iii) the presence typical symptoms. Following these criteria, from the total of 1215 samples for urinalysis or urine culture, 64 (5.3\%) could consider Candida the etiologic agent. The prescription of antifungal treatment should be careful, since the yeast presence in urine may be just due to colonization or contamination. Thus, it is important that the adoption of such therapy is supported by consistent laboratory results and patient's clinical history.

For identification of yeasts of medical interest, the Agência Nacional de Vigilância Sanitária (ANVISA) preconizes urease test and the nitrogen assimilation to major genres differentiation, and to species differentiation of, the recommended test are the germ tube and cornmeal agar microcultivation ${ }^{(3)}$. Candida albicans identification may be performed by the positivity of one or both tests. However, other species cultivation requires additional tests. Therefore, in general, the identification is limited to just differentiate $C$. albicans from other species. Cultivation in chromogenic medium has excellent correlation with traditional tests ${ }^{(22)}$ and, moreover, it is simple to implement, becoming an important tool in laboratory diagnosis ${ }^{(1)}$.

Gomes et al. (2010) ${ }^{(10)}$ performed a study similar to this, in the city of Iguatu-CE, they also found higher prevalence of Candida albicans in urine samples of outpatients (45\%). Despite their percentage was lower than that we found here (67.2\%), this specie is still the most prevalent in outpatients. In Oliveira et al. (2001) ${ }^{(15)}$ study, the major specie isolated in hospitalized patients was Candida tropicalis (53\%), whereas C. albicans prevalence was $36 \%$. According to Kauffman $(2005)^{(12)}$, certain medical procedures, such as bladder catheterization, renal transplantation, and use of antibiótica and corticosteroids, may promote urinary tract infection by non-albicans Candida.

According to Pfaller et al. (2004) ${ }^{(18)}$, some yeasts resistance to fluconazole may be explained by previous exposure to the drug. Because it is a first choice drug for treatment, mainly due to its low toxicity when compared to other antifungals, it is one of the most commonly used antifungal in clinical practice, which leads to selecting resistant strains. When some fungi species are resistant to fluconazole, the second treatment option is amphotericin B, which, in this study, proved to be very effective. However, according to Safdar et al. (2010) ${ }^{(20)}$, this drug should be carefully administrated and used only in cases of proven resistance to other antifungals due to its high toxicity.

When analyzing the data of antifungal susceptibility test, it is possible to observe that non-albicans species have a widely resistance profile, despite the small number of samples when compared to $C$. albicans. These species showed higher percentage of resistance strains to fluconazole and itraconazole. Similar picture was observed by Demitto et al. (2012) $)^{(9)}$, they evaluate the resistance profile of different Candida species isolated from varied clinical samples, including urine at a hospital in Maringá-PR. The authors found a resistance percentage to itraconazole and fluconazole of $68.8 \%$ and $50 \%$, respectively, in C. glabrata strains. For C. krusei, these percentages were 35\% and 100\%, respectively. C. albicans strains also showed higher susceptibility compared to other species. However, $C$. albicans strains studied here showed higher resistance profile when compared with the above-mentioned study. From the total strains here evaluated, $53.5 \%$ were susceptible to itraconazole and fluconazole, while the 
authors of the study found susceptibility of $89.5 \%$ and $100 \%$ to the same antifungals, respectively. Differences in resistance profiles may be due to more or less use of antifungals in each region and, moreover, hospital strains often have higher resistance ${ }^{(6)}$.

Treatment for urinary tract infections is not always performed based on microbiologic examination; it is common the empiric treatment based on epidemiological data. However, this empiric therapy does not consider yeasts as possible causative agents, endangering patient's health, and masking important epidemiological data.

\section{CONCLUSION}

Isolated yeast species showed higher resistance to fluconazole and itraconazole antifungal, this may be due to previous exposure to these drugs, since they are first choice drugs. Statiscally significant difference was found in rates of resistance to fluconazole and itraconazole among species. This finding reinforces the need to perform microbiological examination to better guide treatment, especially when patient has risk factors for developing fungal infections.

\section{RESUMO}

Introdução: 0 termo candidúria designa a presença de leveduras na urina e Candida albicans é o agente mais comum. Em geral, os laboratórios de rotina não realizam o cultivo e a identificação da levedura. Objetivos: Determinar a prevalência de espécies de Candida e avaliar o perfil de sensibilidade aos antifúngicos das espécies isoladas em urina de pacientes ambulatoriais do município de Jatai-GO, entre janeiro e outubro de 2013. Material e método: Amostras de urina que continham estruturas fúngicas foram semeadas em ágar Sabouraud com cloranfenicol. A diferenciação foi feita com provas da urease, assimilação de fontes de nitrogênio e carbono, tubo germinativo, morfologia em ágar fubá e cultivo em ágar cromogênico. Foi avaliada a sensibilidade aos antifúngicos itraconazol, fluconazol, anfotericina B e cetoconazol. Resultados: Foram realizados 1.215 exames de urina, sendo que 64 apresentaram estruturas fúngicas (5,3\%). Houve perda de duas amostras, assim, considerou-se 62 isolados. Desse total, 43 foram identificadas como C. albicans (67,2\%); oito, C. glabrata (12,5\%); cinco, C. krusei (7,8\%); três, C. tropicalis (4,7\%); e em três não foi possivel determinar a espécie (4,7\%). Anfotericina B e cetoconazol inibiram 94,9\% dos isolados. Por outro lado, 55,9\% e 54,2\%, respectivamente, apresentaram resistência a itraconazol e fluconazol. As taxas de resistência a itraconazol e fluconazol de C. glabrata e C. albicans e também do fluconazol entre C. albicans $e$ C. krusei apresentaram diferenças significativas ( $<0,05)$. Conclusão: Os dados demonstram a importância de se realizar a identificação completa e também o antifungigrama para amostras que apresentam infecção por leveduras.

Unitermos: antifungigrama; anfotericina B; Candida; candidúria; cetoconazol; fluconazol; itraconazol.

\section{REFERENCES}

1. ALFONSO, C. et al. Identificación presuntiva de Candida spp. y de otras leveduras de importância clínica: utilidad de Brilliance Candida Agar. Rev Iberoam Micol, v. 27, n. 2, p. 90-3, 2010.

2. ATIQUE, T. S. C. Pesquisa das espécies e sensibilidade antifúngica de Candida sp. em indivíduos soropositivos para o HIV. São José do Rio Preto, 2006. Dissertação de Mestrado. Programa de Pós-Graduação em Ciências da Saúde, Faculdade de Medicina de São José do Rio Preto, 2006.

3. BRASIL. Agência Nacional de Vigilância Sanitária (ANVISA). Detecção e identificação dos fungos de importância médica. Módulo VII, 2004. Available at: <http://www.anvisa.gov.br/servicosaude/microbiologia/ mod_7_2004.pdf>. Accessed on: Jun. 25, 2013.

4. BUKHARY, Z. A. Candiduria: a review of clinical significance and management. Saudi J Kidney Dis Transpl, v. 19, n. 3, p. 350-60, 2008.

5. CANUTO, M. M.; RODERO, F. G. Antifungal drug resistance to azoles and polyenes. Lancet Infect Dis, v. 2, n. 9, p. 550-63, 2002.
6. CASTRO, T. L. et al. Mecanismos de resistência da Candida sp. a antifúngicos. Infarma, v. 18, n. 9, p. 9-10, 2006.

7. CLINICAL AND LABORATORY STANDARDS INSTITUTE. Method for antifungal disk diffusion susceptibility testing of yeasts: approved guideline M44-A2. CLSI, Wayne, PA, USA, 2010.

8. COLOMBO, A. L.; GUIMARÃES, T. Candidúria: uma abordagem clínica e terapêutica. Rev Soc Bras Med Trop, v. 40, n. 3, p. 332-7, 2007.

9. DEMITTO, F. 0. et al. Suscetibilidade a antifúngicos in vitro de Candida spp. em pacientes do Hospital Universitário Regional de Maringá-PR.J Bras Patol Med Lab, v. 48, n. 5, p. 315-21, 2012.

10. GOMES, C. L. et al. Identificação e perfil de sensibilidade de Candida $s p p$. isoladas de urina de pacientes com candidúria em Iguatu-Ceará. $R B A C$, v. 42, n. 3, p. 223-5, 2010.

11. GULER, S. et al. Risk factors for nosocomial candiduria. Saudi Med J, v. 27, n. 11, p. 1706-10, 2006.

12. KAUFFMAN, C. A. Candiduria. Clin Infect Dis, v. 41 (Suppl 6), p. 371-6, 2005. 
13. KAUFFMAN, C. A. et al. Prospective multicenter surveillance study of funguria in hospitalized patients. Clin Infect Dis, v. 30, n. 1, p. $14-8,2000$.

14. MALANI, A. N.; KAUFFMAN, C. A. Candida urinary tract infections: treatment options. Expert Rev Anti Infect Ther, v. 5, n. 2, p. 277-84, 2007.

15. OLIVEIRA, R. D. R. et al. Infecção urinária hospitalar por leveduras do gênero Candida. Rev Ass Med Bras, v. 47, n. 3, p. 231-5, 2001.

16. OLIVEIRA, N. C. et al. Use of chromogenic medium and semi-nested PCR-based assay to identify Candida species. Semina, v. 27, n. 2, p. 12532, 2006.

17. PASSOS, X. S. et al. Candida colonization in intensive care unit patients urine. Mem Inst Oswaldo Cruz, v. 100, n. 8, p. 925-8, 2005.
18. PFALLER, M. A. et al. Comparison of results of fluconazole disk diffusion testing for Candida.J Clin Microbiol, v. 42, n. 8, p. 3607-12, 2004.

19. RODRIGUES, D. et al. Candidúria: revisão atual. RBPS, v. 24, n. 2, p. $142-50,2011$.

20. SAFDAR, A. et al. Drug-induced nephrotoxicity caused by amphotericin B lipid complex and liposomal amphotericin B: a review and metaanalysis. Medicine, v. 89, n. 4, p. 236-44, 2010.

21. SOBEL, J. D. The emergence of non-albicans Candida species as causes of invasive candidiasis and candidemia. Curr Infect Dis Rep, v. 8, n. 6, p. 427-33, 2006.

22. WINN, W. et al. Micologia. In: KONEMAN, E. Diagnóstico microbiológico: texto e atlas colorido. 6. ed. Rio de Janeiro: Guanabara Koogan, 2008. Cap. 21; p. 1145-236. 